Zeszyty Naukowe Szkoły Głównej Gospodarstwa Wiejskiego

Ekonomika i Organizacja Gospodarki Żywnościowej nr 114, 2016: 143-155

Małgorzata Kosicka-Gębska, Jerzy Gębski, Katarzyna Kwiecińska

Szkoła Główna Gospodarstwa Wiejskiego w Warszawie

\title{
Ocena informacji zawartych na etykiecie pakowanej wieprzowiny
}

\section{Wstęp}

Zwracając uwagę na strukturę spożycia mięsa w Polsce, można zauważyć, że dominująca pozycję (podobnie jak i w produkcji) zajmuje wieprzowina (ok. 60\%). Według szacunków prowadzonych przez Główny Urząd Statystyczny, Instytut Ekonomiki Rolnictwa i Gospodarki Żywnościowej - PIB, Agencję Rynku Rolnego i Ministerstwo Rolnictwa i Rozwoju Wsi, poziom spożycia mięsa wieprzowego utrzymuje się obecnie, jak i na początku lat 90 . na poziomie około $37 \mathrm{~kg} /$ osobę/rok (tabela 1). Jest on zbliżony do poziomu spożycia we Francji, Irlandii, i Włoszech, w których to krajach wynosi ono 36-38 kg/osobę/rok, natomiast jest zdecydowanie niższy w porównaniu do Hiszpanii $(58-66 \mathrm{~kg} / \mathrm{oso}-$ bę/rok), Danii (63-64 kg/osobę/rok), Niemiec czy Austrii (56-57 kg/osobę/rok). Można stwierdzić, że pomimo zmieniających się zwyczajów żywieniowych Polaków przejawiających się np. wzrostem poziomu spożycia mięsa drobiowego z 7,6 kg/osobę/rok w 1990 roku do $28,0 \mathrm{~kg} /$ osobę/rok w 2014 roku, mięso wieprzowe jest wciąż tradycyjnym składnikiem polskiej diety oraz polskiej kuchni, często kojarzonym z latami dzieciństwa [Połom i Baryłko-Piekielna 2004; Zachowania i nawyki... 2010].

Wieprzowina jako rodzaj mięsa od lat budzi kontrowersje wśród dietetyków, którzy przede wszystkim zwracają uwagę na jej kaloryczność, niekorzystny profil kwasów tłuszczowych i twierdza, że nie powinna być ona składnikiem racjonalnej diety. Badania naukowe wykazują istotną zależność pomiędzy spożywaniem wieprzowiny a rozwojem chorób, takich jak: choroby sercowo-naczyniowe, otyłość i niektóre rodzaje nowotworów [Valsta i in. 2005; Cross i in. 2010].

$\mathrm{Z}$ drugiej strony zwraca się uwagę, że wieprzowina jest źródłem licznych substancji odżywczych, przede wszystkim białka, w którego składzie znajdują się prawie wszystkie niezbędne aminokwasy. Zawiera znaczące ilości tiaminy 
Tabela 1

Spożycie mięsa w Polsce w latach 1990-2014 [w kg na 1 mieszkańca]

\begin{tabular}{|c|c|c|c|c|}
\hline \multirow{3}{*}{ Lata } & \multicolumn{4}{|c|}{ Mięso łącznie z podrobami } \\
\hline & \multirow{2}{*}{ ogółem } & \multicolumn{3}{|c|}{ w tym: mięso bez podrobów } \\
\hline & & wieprzowe & wołowe & drobiowe \\
\hline 1990 & 68,8 & 37,7 & 16,4 & 7,6 \\
\hline 1991 & 73,5 & 42,2 & 15,7 & 8,2 \\
\hline 1992 & 70,7 & 42,4 & 12,7 & 9,1 \\
\hline 1993 & 67,9 & 40,8 & 11,5 & 9,5 \\
\hline 1994 & 63,1 & 37,5 & 9,1 & 10,7 \\
\hline 1995 & 64,0 & 39,4 & 8,8 & 10,3 \\
\hline 1996 & 65,2 & 40,4 & 8,6 & 10,3 \\
\hline 1997 & 62,3 & 35,7 & 8,4 & 12,5 \\
\hline 1998 & 65,3 & 38,0 & 8,2 & 13,2 \\
\hline 1999 & 67,5 & 40,0 & 7,9 & 14,0 \\
\hline 2000 & 66,1 & 39,0 & 7,1 & 14,7 \\
\hline 2001 & 66,6 & 38,6 & 5,6 & 17,2 \\
\hline 2002 & 69,5 & 39,2 & 5,2 & 19,8 \\
\hline 2003 & 72,1 & 41,2 & 5,8 & 19,7 \\
\hline 2004 & 71,8 & 39,1 & 5,3 & 22,2 \\
\hline 2005 & 71,2 & 39,0 & 3,9 & 23,4 \\
\hline 2006 & 74,3 & 41,4 & 4,5 & 23,7 \\
\hline 2007 & 77,6 & 43,6 & 4,0 & 24,0 \\
\hline 2008 & 75,3 & 42,7 & 3,8 & 24,1 \\
\hline 2009 & 75,2 & 41,9 & 3,6 & 24,3 \\
\hline 2010 & 73,7 & 42,2 & 2,4 & 24,6 \\
\hline 2011 & 73,4 & 42,5 & 2,1 & 25,0 \\
\hline 2012 & 71,0 & 39,2 & 1,6 & 26,1 \\
\hline 2013 & 68,1 & 35,5 & 1,5 & 27,3 \\
\hline $2014^{*}$ & 70,0 & 36,5 & 1,5 & 28,0 \\
\hline
\end{tabular}

Źródło: Opracowanie na podstawie: Rynek mięsa - stan i perspektywy, 2014: Analizy rynkowe, IERiGŻ-PIB, ARR, MRiRW, czerwiec, 46, 56; *prognoza IERGŻ i PIB.

(witaminy $\mathrm{B}_{1}$ ), która pełni ważną rolę w procesach energetycznych, neurofizjologicznych i metabolicznych; wchodzi w skład wielu enzymów, uczestniczących w przemianie węglowodanów. Jest także źródłem niacyny (witaminy PP), a podroby wieprzowe (wątroba, nerki) są dobrym źródłem witamin A, D i K. Mięso wieprzowe, a zwłaszcza podroby, zawierają także duże ilości składników mineralnych przede wszystkim dobrze przyswajalne żelazo, cynk i miedź [Kontogianni i in. 2008; Cegiełka 2010]. Jest ono również cennym źródłem związków bioaktywnych dla organizmu człowieka. Należą do nich: tauryna, karnozyna, koenzym Q10 (ubichinon) kreatyna [Biesalski 2005; Sadowska i Świderski 2010].

Stałe zainteresowanie konsumentów mięsem wieprzowym powoduje konieczność dostosowania cech sensorycznych, jak również sposobu opakowania do oczekiwań konsumentów. Zmiany w sposobie odżywiania się Polaków, 
związane z większą świadomością żywieniowo-zdrowotną, wymusiły na producentach żywności nowe sposoby produkcji wieprzowiny. Cechuje się ona obecnie wysoką jakością oraz mniejszą zawartością tłuszczu, a także coraz częściej zwiększonym udziałem wielonienasyconych kwasów tłuszczowych z rodziny n-3, a tym samym obniżeniem niekorzystnego stosunku n-6 do n-3, który w diecie człowieka powinien wynosić $4: 1$ [McAfee i in. 2010; Piotrowska i in. 2012].

W ostatnich latach coraz częściej dowodzi się, że kluczową rolę przy podejmowaniu decyzji o zakupie żywności odgrywa informacja o produkcie, która może być przekazywana do konsumenta na wiele różnych sposobów. Istotne znaczenie mogą mieć źródła osobiste, czyli informacje uzyskane na podstawie własnego doświadczenia (poszukiwanie produktów na rynku, degustacja) czy też źródła marketingowe prezentujące informacje pochodzące z reklam, wystaw, ze sprzedaży osobistej, czy informacje na opakowaniu. Informacje formalne są przekazywane konsumentom w formie odpowiednich oznaczeń, do których można zaliczyć wyrazy, znaki i symbole. Jak potwierdza wiele badań, dla współczesnego konsumenta treść etykiety stanowi podstawowe źródło wiedzy o produkcie i sposobie jego użytkowania oraz jest dokumentem odzwierciedlającym jego jakość [Verbeke i Viaene 1999; Roosen i in. 2001; Grunert i Wills 2007; Verbeke i in. 2010].

Badania konsumentów mięsa i jego przetworów prowadzone nie tylko w Polsce, ale także w innych krajach europejskich potwierdzają ich zainteresowanie i oczekiwania względem umieszczania różnych informacji na etykietach produktów [Yen i in. 2008; Walkowska i Rejman 2012].

Etykieta informuje konsumenta o samym produkcie i jego cechach, o marce, do której przynależy produkt oraz pozwala odróżnić i znaleźć ten konkretny produkt pośród setek innych na półce sklepowej. Można zatem śmiało stwierdzić, że etykieta, a w szczególności informacje na niej zawarte, nawiązują dialog z konsumentem - odpowiadają na jego potrzeby i pytania, przekazując właściwe komunikaty wizualno-tekstowe [Verbeke i Viaene 2000].

Chcąc ujednolicić przepisy dotyczące znakowania żywności w całej Unii Europejskiej, przyjęto rozporządzenie Parlamentu Europejskiego i Rady (UE) nr 1169/2011 z dnia 25 października 2011 roku w sprawie przekazywania konsumentom informacji o żywności. Rozporządzenie to weszło w życie w dniu 13 grudnia 2014 roku, obowiązuje w całości we wszystkich państwach Unii Europejskiej i ma zastosowanie do produktów spożywczych przeznaczonych dla konsumenta finalnego na każdym etapie łańcucha żywnościowego. Dzięki tym zmianom zasad etykietowania żywności, konsumenci powinni mieć do dyspozycji podstawowe, czytelne i zrozumiałe informacje umożliwiające świadomy zakup produktów. Istotną zmianą jest m.in. wskazanie w Rozporządzeniu nr 1169/2011 zalecenia, że etykiety żywności powinny być jasne i zrozumiałe, 


\section{6}

aby były pomocne dla konsumentów, którzy chcą dokonywać bardziej świadomych wyborów dotyczących żywności i diety. Nowe wymagania dotyczą także minimalnej wysokości czcionki, jaką mają być podawane na etykietach informacje obowiązkowe, aby były dla konsumenta lepiej widoczne. Dzięki temu zapewniona będzie większa czytelność etykiet dla każdego konsumenta. W Rozporządzeniu nr 1169/2011 określono, że wysokość małych liter powinna wynosić co najmniej 1,2 mm (Rozporządzenie... 2011).

W gospodarce rynkowej coraz bardziej świadomi swoich praw i chętni wzbogacania wiedzy konsumenci chcą uczestniczyć w tworzeniu nie tylko cech sensorycznych produktów żywnościowych (np. wygląd, zapach, tekstura), ale również w kreowaniu wizerunku produktów. W tworzeniu tego ostatniego istotne znaczenie może odgrywać opakowanie i etykieta [Grunert i Wills 2007; Wills i in. 2009]. Stąd też celem przeprowadzonego badania ilościowego była ocena poziomu zrozumiałości i widoczności informacji znajdujących się na etykietach pakowanej wieprzowiny. Uzyskana ocena pozwoliła na stwierdzenie, czy obowiązujące wymagania legislacyjne znajdują odzwierciedlenie w oczekiwaniach konsumentów. Otrzymane wyniki badania mogą posłużyć producentom i handlowcom do przygotowania etykiety mięsa wieprzowego nie tylko zgodnie z obowiązującymi wymogami prawnymi, ale również z uwzględnieniem preferencji konsumentów.

\section{Materiał i metody}

Ilościowe badanie empiryczne przeprowadzono w 2012 roku na próbie 1325 respondentów powyżej 16. roku życia, którzy deklarowali regularne spożywanie wieprzowiny. Miało ono charakter badania ogólnopolskiego. Zostało przeprowadzone przez agencję badawczą w 16 województwach, proporcjonalnie do liczby ich mieszkańców. W każdym województwie liczebność próby została ustalona zgodnie $\mathrm{z}$ faktycznymi proporcjami występującymi w tym województwie (na podstawie danych statystycznych - Bank Danych Lokalnych) dla kryteriów takich, jak: płeć, wiek, wykształcenie i miejsce zamieszkania. Badanie to zostało zrealizowane w ramach projektu finansowanego przez Narodowe Centrum Nauki w Krakowie pt. Uwarunkowania wyboru i konsumpcji mięsa w Polsce - diagnoza i prognozy, numer projektu: 3938/B/H03/2011/40.

Metodą badawczą zastosowaną w badaniu był wywiad osobisty. Do jego przeprowadzenia przygotowano autorski kwestionariusz wywiadu. Dotyczył on zagadnien, takich jak: preferencje konsumentów związane $\mathrm{z}$ wyborem paczkowanego lub niepaczkowanego mięsa wieprzowego, oceny zrozumiałości i widoczności informacji znajdujących się na etykiecie mięsa paczkowanego oraz oczekiwań badanych konsumentów wobec konieczności umieszczania odpowiednich treści 
informacji na etykiecie w przyszłości. Do oceny zrozumiałości i widoczności informacji umieszczonych na paczkowanej wieprzowinie wykorzystano 5-stopniowa skalę ocen, gdzie ocenę na poziomie 1 interpretowano jako informację bardzo mało zrozumiałą lub bardzo mało widoczną, a ocena 5 oznaczała, że zrozumiałość i widoczność informacji jest bardzo dobra. Do poznania oczekiwań badanych wobec treści informacji na etykiecie posłużyło 6 stwierdzeń, które w dalszej części pracy przedstawia tabela 5 .

W celu analizy zgromadzonego materiału empirycznego do wstępnego poznania rozkładu zmiennych zastosowano analizę częstości. Do zbadania związku między zmiennymi wykorzystano test $\mathrm{chi}^{2}$ Pearsona, a do określenia siły zależności między cechami obliczono współczynnik korelacji R Spearmana. Analizy przeprowadzono z wykorzystaniem programu SPSS for Windows PL 21.

W ogólnopolskim badaniu 55,4\% stanowiły kobiety. Analizując subiektywne opinie o posiadanym przez respondentów dochodzie, stwierdzono, że najwięcej z nich $(37,6 \%)$ uważało, że jego poziom pozwala na zaspokojenie tylko podstawowych potrzeb, a dla $21,8 \%$ badanych posiadany dochód był niewystarczający. Zwracając uwagę na miejsce zamieszkania respondentów, stwierdzono, że około $38 \%$ badanych reprezentowało wieś jako miejsce zamieszkania, 35,5\% to mieszkańcy miast poniżej 500 tys. mieszkańców, a $26,8 \%$ to przedstawiciele miast powyżej 500 tys. mieszkańców (tabela 2).

\section{Wyniki}

Analizując odpowiedzi respondentów związane z ich preferencjami wobec wieprzowiny, a w szczególności dotyczące jej wyboru w formie pakowanej lub luzem, stwierdzono, że ponad 3/5 badanych kupowało mięso pakowane (tabela 2), co potwierdza konieczność podejmowania badań dotyczących poznania poziomu zadowolenia konsumentów z informacji obecnie umieszczanych na etykiecie, a także poznanie oczekiwań wobec treści i sposobów przekazywanych informacji. Uzyskane wyniki świadczą o zmianach zwyczajów konsumentów podczas zakupu mięsa. W kontekście otrzymanych danych zauważano, że zaledwie kilka lat temu, konsumenci najczęściej kupowali surowe mięso „luzem” [Walkowiak $\mathrm{i}$ in. 2012].

Stwierdzono, że do zakupu mięsa wieprzowego pakowanego istotnie statystycznie częściej przyznawali się mężczyźni, osoby reprezentujące środowisko miejskie oraz badani, którzy deklarują, że „stać ich na niektóre, ale nie wszystkie wydatki". Dla porównania, mięso luzem/niepakowane chętniej kupowały kobiety, mieszkańcy wsi, a także osoby, które są zdania, że posiadany dochód ,pozwala na zaspokojenie tylko podstawowych potrzeb" lub ,jest niewystarczający". 
Tabela 2

Preferencje respondentów związane z wyborem pakowanego lub niepakowanego mięsa wieprzowego [\%]

\begin{tabular}{|c|c|c|c|c|}
\hline \multirow[t]{3}{*}{ Cała populacja } & \multirow[t]{2}{*}{$\begin{array}{c}\text { Ogółem } \\
N=1325\end{array}$} & \multicolumn{2}{|c|}{$\begin{array}{l}\text { Preferencje nabywcze konsu- } \\
\text { mentów wobec wyboru formy } \\
\text { opakowania mięsa wieprzowego }\end{array}$} & \multirow{3}{*}{$\begin{array}{c}\text { Istotność } \\
\text { statystyczna }\end{array}$} \\
\hline & & niepakowane & pakowane & \\
\hline & $100 \%$ & 34,2 & 65,8 & \\
\hline $\begin{array}{l}\text { Płeć } \\
\text { Kobieta } \\
\text { Mężczyzna }\end{array}$ & $\begin{array}{l}55,4 \\
44,6\end{array}$ & $\begin{array}{l}51,3 \\
48,7\end{array}$ & $\begin{array}{l}27,4 \\
72,6\end{array}$ & $\begin{array}{c}\text { IS } \\
\mathrm{chi}^{2}=52,32 \\
r=0,351, p<0,05\end{array}$ \\
\hline $\begin{array}{l}\text { Opinia o dochodzie } \\
\text { Jest niewystarczający } \\
\text { Pozwala na zaspoko- } \\
\text { jenie tylko podstawo- } \\
\text { wych potrzeb } \\
\text { Stać nas na niektóre, } \\
\text { ale nie wszystkie } \\
\text { wydatki } \\
\text { Stać nas na wszystko } \\
\text { Stać nas na wszystko } \\
\text { i możemy zaoszczę- } \\
\text { dzić }\end{array}$ & $\begin{array}{l}11,4 \\
12,1\end{array}$ & $\begin{array}{c}17,3 \\
9,7\end{array}$ & $\begin{array}{l}29,1 \\
15,3\end{array}$ & $\begin{array}{c}\text { IS } \\
\mathrm{chi}^{2}=31,90 \\
\mathrm{r}=0,250, \mathrm{p}<0,05\end{array}$ \\
\hline $\begin{array}{l}\text { Miejsce zamieszkania } \\
\text { Miasto pow. } 500 \text { tys. } \\
\text { mieszkańców } \\
\text { Miasto poniżej } 500 \text { tys. } \\
\text { mieszkańców } \\
\text { Wieś }\end{array}$ & $\begin{array}{l}35,5 \\
37,7\end{array}$ & $\begin{array}{l}24,2 \\
58,5\end{array}$ & $\begin{array}{l}33,8 \\
23,8\end{array}$ & $\begin{array}{c}\text { IS } \\
\mathrm{chi}^{2}=46,20 \\
r=-0,319, p<0,05\end{array}$ \\
\hline
\end{tabular}

IS - występuje istotność statystyczna między zmiennymi; NS - brak istotności statystycznej. Źródło: Badanie własne.

Podejmując $\mathrm{w}$ pracy próbę oceny zrozumiałości i widoczności informacji znajdujących się na etykiecie wieprzowego mięsa pakowanego, na podstawie danych zawartych w tabeli 3 stwierdzono, że dla prawie 3/5 badanych informacje zamieszczane na etykiecie są mało zrozumiałe. Świadczy o tym przewaga ocen na poziomie „1 i 2 ”. Zaledwie $10 \%$ respondentów uważa informacje na etykiecie wieprzowiny za bardzo dobrze zrozumiałe ( $9,6 \%$ ocen na poziomie „5”).

Zwracając uwagę na zróżnicowanie odpowiedzi badanych pod względem charakteryzujących ich cech socjoekonomiczno-demograficznych zauważono, że poziom wykształcenia respondentów oraz wiek wykazują w tym przypadku znaczenie istotne statystycznie. Stwierdzono, że wraz ze wzrostem poziomu wykształcenia, wzrasta procentowy udział odpowiedzi świadczących o lepszej zrozumiałości informacji pochodzących z etykiet mięsa. Uwzględniając wpływ wieku badanych na oceny dotyczące zrozumiałości informacji, zauważono, że 
Tabela 3

Ocena poziomu zrozumiałości przez respondentów informacji na etykiecie pakowanego mięsa wieprzowego [\%]

\begin{tabular}{|c|c|c|c|c|c|c|c|}
\hline \multirow{3}{*}{ Cała populacja } & \multirow[t]{2}{*}{$\begin{array}{c}\text { Ogółem } \\
\mathrm{N}=1325\end{array}$} & \multicolumn{5}{|c|}{$\begin{array}{c}\text { Ocena zrozumiałości informacji } \\
\text { na etykiecie pakowanego mięsa } \\
\text { wieprzowego }\end{array}$} & \multirow{3}{*}{$\begin{array}{c}\text { Istotność } \\
\text { statystyczna }\end{array}$} \\
\hline & & 1 & 2 & 3 & 4 & 5 & \\
\hline & $100 \%$ & 38,2 & 20,1 & 17,5 & 14,6 & 9,6 & \\
\hline $\begin{array}{l}\text { Poziom } \\
\text { wykształcenia: } \\
\text { podstawowe } \\
\text { zasadnicze } \\
\text { zawodowe } \\
\text { średnie } \\
\text { wyższe } \\
\end{array}$ & $\begin{array}{l}14,5 \\
\\
17,2 \\
38,2 \\
30,1 \\
\end{array}$ & $\begin{array}{c}42,1 \\
\\
31,8 \\
18,1 \\
8,0 \\
\end{array}$ & $\begin{array}{l}32,6 \\
\\
19,5 \\
20,1 \\
27,8 \\
\end{array}$ & $\begin{array}{l}15,0 \\
18,1 \\
37,2 \\
29,7 \\
\end{array}$ & $\begin{array}{l}7,9 \\
\\
18,7 \\
20,3 \\
53,1 \\
\end{array}$ & $\begin{array}{l}15,5 \\
\\
17,0 \\
31,3 \\
36,2 \\
\end{array}$ & $\begin{array}{c}\text { IS } \\
\mathrm{chi}^{2}=72,64 \\
r=0,215 \\
p<0,05\end{array}$ \\
\hline $\begin{array}{l}\text { Wiek: } \\
\text { 18-25 } \\
26-35 \\
36-45 \\
46-55 \\
56 \text { i więcej } \\
\end{array}$ & $\begin{array}{l}12,3 \\
38,2 \\
35,2 \\
13,8 \\
28,1 \\
\end{array}$ & $\begin{array}{l}13,3 \\
20,2 \\
19,1 \\
19,8 \\
27,4 \\
\end{array}$ & $\begin{array}{c}2,9 \\
16,7 \\
25,8 \\
35,2 \\
19,4 \\
\end{array}$ & $\begin{array}{c}15,8 \\
34,2 \\
22,1 \\
9,3 \\
18,6 \\
\end{array}$ & $\begin{array}{l}25,7 \\
29,2 \\
18,1 \\
10,5 \\
16,4 \\
\end{array}$ & $\begin{array}{l}29,7 \\
31,2 \\
16,5 \\
15,6 \\
7,0 \\
\end{array}$ & $\begin{array}{c}\text { IS } \\
\text { chi }^{2}=151,01 \\
r=-0,203, \\
p<0,05\end{array}$ \\
\hline $\begin{array}{l}\text { Zwracanie uwagi } \\
\text { na informacje } \\
\text { umieszczone } \\
\text { na opakowaniu } \\
\text { Tak } \\
\text { Nie }\end{array}$ & $\begin{array}{l}38,2 \\
61,8\end{array}$ & $\begin{array}{l}36,6 \\
63,4\end{array}$ & $\begin{array}{l}34,9 \\
65,1\end{array}$ & $\begin{array}{l}46,8 \\
53,2\end{array}$ & $\begin{array}{l}58,5 \\
41,5\end{array}$ & $\begin{array}{l}60,8 \\
39,2\end{array}$ & NS \\
\hline
\end{tabular}

IS - występuje istotność statystyczna między zmiennymi; NS - brak istotności statystycznej. Źródło: Badanie własne.

są one lepiej zrozumiałe dla osób reprezentujących przedział wiekowy 18-25 lat oraz 26-35 lat w porównaniu do respondentów ze starszych grup wiekowych.

Dane przedstawione w tabeli 4 dowodza, że ponad $1 / 2$ badanych informacje umieszczone na pakowanym mięsie wieprzowym ocenia jako mało widoczne, o czym świadczy przewaga ocen na poziomie „1 i 2”.

$\mathrm{Na}$ ocenę widoczności informacji na etykiecie, istotnie statystycznie wpływają zmienne, do których zaliczyć można płeć badanych i poziom ich wykształcenia. Stwierdzono, że kobiety częściej od mężczyzn oceniają na wyższym poziomie widoczność informacji zawartych na etykiecie $(61,5 \%$ ocen na poziomie ,5”), podobnie jak respondenci z wyższym poziomem wykształcenia $(33,4 \%$ ocen na poziomie ,5”).

Jak stwierdzono, dla polskich konsumentów informacje zawarte na etykiecie paczkowanego mięsa wieprzowego, w świetle analizy zgromadzonych danych empirycznych, są mało zrozumiałe i jednocześnie mało czytelne. Podobne 
Tabela 4

Ocena widoczności informacji na etykiecie pakowanego mięsa wieprzowego [\%]

\begin{tabular}{|c|c|c|c|c|c|c|c|}
\hline \multirow{3}{*}{ Cała populacja } & \multirow[t]{2}{*}{$\begin{array}{l}\text { Ogółem } \\
\mathrm{N}=1325\end{array}$} & \multicolumn{5}{|c|}{$\begin{array}{c}\text { Ocena widoczności informacji } \\
\text { na etykiecie pakowanego mięsa } \\
\text { wieprzowego }\end{array}$} & \multirow{3}{*}{$\begin{array}{l}\text { Istotność } \\
\text { statystycz- } \\
\text { na }\end{array}$} \\
\hline & & 1 & 2 & 3 & 4 & 5 & \\
\hline & $100 \%$ & 29,1 & 25,2 & 10,7 & 18,9 & 16,1 & \\
\hline $\begin{array}{l}\text { Płeć } \\
\text { Kobieta } \\
\text { Mężczyzna }\end{array}$ & $\begin{array}{l}57,2 \\
48,2\end{array}$ & $\begin{array}{l}46,1 \\
53,9\end{array}$ & $\begin{array}{l}37,2 \\
62,8\end{array}$ & $\begin{array}{l}50,1 \\
49,9\end{array}$ & $\begin{array}{l}54,8 \\
45,2\end{array}$ & $\begin{array}{l}61,5 \\
38,5\end{array}$ & $\begin{array}{c}\text { IS } \\
\text { chi }^{2}=31,25 \\
r=-0,172 \\
p<0,05\end{array}$ \\
\hline $\begin{array}{l}\text { Poziom wykształcenia: } \\
\text { podstawowe } \\
\text { zasadnicze zawodowe } \\
\text { średnie } \\
\text { wyższe }\end{array}$ & $\begin{array}{l}14,5 \\
17,2 \\
38,2 \\
30,1\end{array}$ & $\begin{array}{l}35,8 \\
25,6 \\
12,2 \\
26,4\end{array}$ & $\begin{array}{l}45,6 \\
22,1 \\
17,9 \\
14,4\end{array}$ & $\begin{array}{l}25,5 \\
19,8 \\
29,6 \\
25,1\end{array}$ & $\begin{array}{c}9,6 \\
25,8 \\
47,2 \\
17,4 \\
\end{array}$ & $\begin{array}{l}20,2 \\
17,8 \\
28,6 \\
33,4\end{array}$ & $\begin{array}{c}\text { IS } \\
\text { chi }^{2}=77,44 \\
r=-0,215 \\
p<0,05\end{array}$ \\
\hline $\begin{array}{l}\text { Zwracanie uwagi na } \\
\text { informacje umieszczone } \\
\text { na opakowaniu } \\
\text { Tak } \\
\text { Nie }\end{array}$ & $\begin{array}{l}38,2 \\
61,8\end{array}$ & $\begin{array}{l}34,6 \\
65,4\end{array}$ & $\begin{array}{l}22,8 \\
77,2\end{array}$ & $\begin{array}{l}21,4 \\
78,6\end{array}$ & $\begin{array}{l}20,9 \\
79,1\end{array}$ & $\begin{array}{l}24,8 \\
75,2\end{array}$ & NS \\
\hline
\end{tabular}

IS - występuje istotność statystyczna między zmiennymi; NS - brak istotności statystycznej. Źródło: Badanie własne.

spostrzeżenia uzyskano w badaniach Tomaszewskiej-Pielachy i Ozimek [2011], a także Kosickiej-Gębskiej [2012].

Warto podkreślić, że także dla konsumentów z innych krajów europejskich informacje zamieszczane na etykietach produktów żywnościowych, w tym pakowanego mięsa są oceniane jako mało widoczne i niezrozumiałe, co potwierdza Report on European Consumer's Percept of Foodstuff Labelling [2005] oraz raport „Consumer Attitudes to Food Standards”, opracowany przez Food Standard Agency [2007]. Stąd też zaleca się umieszczanie ich w bardziej widocznym miejscu, przy jednoczesnym używaniu bardziej zrozumiałych dla konsumentów określeń, zwiększeniu rozmiaru czcionki i poprawieniu ogólnej przejrzystości etykiety.

Zwracając uwagę na potrzeby konsumentów dotyczące ich oczekiwań wobec przekazu informacji, która powinna zostać umieszczona na pakowanym mięsie wieprzowym w przyszłości (tabela 5), stwierdzono konieczność umieszczenia w widocznym miejscu m.in.: informacji o terminie przydatności mięsa do spożycia, stosowania zróżnicowanej wielkości czcionki, deklaracji od producenta, że mięso pochodzi ze zwierząt niekarmionych paszami z udziałem organizmów 
Tabela 5

Oczekiwania respondentów wobec informacji umieszczanych na etykiecie pakowanego mięsa wieprzowego [\%]

\begin{tabular}{|l|c|c|c|}
\hline Odpowiedzi respondentów & \multirow{2}{*}{$\begin{array}{c}\text { Ogółem } \\
\text { N=1325 }\end{array}$} & \multicolumn{2}{|c|}{ Płeć } \\
\cline { 3 - 4 } & kobieta & mężczyzna \\
\hline Cała populacja & 100 & 57,2 & 42,8 \\
\hline $\begin{array}{l}\text { pełne nazwy substancji dodatkowych (dotychczas } \\
\text { opisywane za pomocą symboli literowych) }\end{array}$ & 19,2 & 19,3 & 19,1 \\
\hline przepisy na wykonanie potrawy & 4,3 & 5,6 & 3,0 \\
\hline $\begin{array}{l}\text { mięso pochodzace ze zwierząt niekarmionych paszami } \\
\text { z udziałem substancji modyfikowanych genetycznie }\end{array}$ & 19,4 & 25,1 & 13,7 \\
\hline ekologiczne pochodzenie mięsa & 1,2 & 1,5 & 0,9 \\
\hline stosowanie zróżnicowanej wielkości czcionki & 26,8 & 27,1 & 26,5 \\
\hline $\begin{array}{l}\text { umieszczenie w widocznym miejscu informacji } \\
\text { o terminie przydatności do spożycia }\end{array}$ & 29,1 & 27,1 & 31,1 \\
\hline
\end{tabular}

Źródło: Badanie własne.

modyfikowanych genetycznie, czy podawania pełnych nazw substancji dodatkowych, jeśli takie zostały zastosowane do produkcji lub przechowywania mięsa.

Analiza udziału procentowego odpowiedzi otrzymanych od respondentów wskazuje, że w najmniejszym stopniu są oni zainteresowani umieszczeniem na etykiecie informacji dotyczących: ekologicznego pochodzenia mięsa $(1,2 \%)$ oraz przepisów kulinarnych ułatwiających przygotowanie potrawy $(4,3 \%)$. Stwierdzono ponadto, że kobiety częściej od mężczyzn, chciałyby widzieć na etykiecie pakowanego mięsa wieprzowego przepis na wykonanie potrawy oraz informację, że mięso pochodzi ze zwierząt niekarmionych paszami z udziałem organizmów modyfikowanych genetycznie.

Wyniki innych badań wskazują że wśród konsumentów europejskich opinie na temat potrzebnych informacji na etykiecie pakowanego mięsa były zróżnicowane w zależności od kraju, który reprezentowali respondenci. I tak, Włosi i Francuzi z etykiety chcieli przede wszystkim uzyskać informacje dotyczące systemu produkcji, identyfikowalności i kontroli jakości. Dla konsumentów hiszpańskich ważnymi kwestiami były: okres dojrzewania, informacja żywieniowa, pochodzenie oraz termin przydatności do spożycia. W przypadku szkockich $i$ angielskich konsumentów stwierdzono najniższe poziomy oceny ważności informacji pochodzących $\mathrm{z}$ etykiety mięsa, $\mathrm{z}$ wyjątkiem informacji o pochodzeniu wołowiny spożywanej przez Szkotów [Bernués i in. 2003]. 


\section{Wnioski}

Celem etykietowania artykułów spożywczych, w tym mięs, jest zagwarantowanie konsumentom dostępu do kompletnych informacji m.in. na temat cen, a przede wszystkim zawartości i składu produktów w celu ochrony ich zdrowia i interesów. Informacje zawarte na produkcie pakowanym mogą zawierać szczegóły dotyczące określonego aspektu produktu, np. jego pochodzenia lub metody wytwarzania. Informacje te pozwalają współczesnym konsumentom na dokonywanie świadomego wyboru na rynku. Powinny spełniać z jednej strony wymogi legislacyjne, a $\mathrm{z}$ drugiej powinny być zgodne $\mathrm{z}$ oczekiwaniami konsumentów. Zgodnie z wytycznymi Rozporządzenia Parlamentu Europejskiego (UE) nr 1169/2011 z dnia 25 października 2011 roku, stosowanym w Polsce od 13 grudnia 2014 roku, informacje te powinny być przede wszystkim dobrze widoczne i zrozumiałe.

Jak wynika z przeprowadzonego badania ilościowego, informacje zawarte na etykietach pakowanego mięsa wieprzowego są dla ponad $1 / 2$ respondentów zarówno mało zrozumiałe, jak i mało widoczne. Dane te dowodzą, że obecnie stosowane etykiety na pakowanej wieprzowinie, nie zaspokajają oczekiwań współczesnych konsumentów. Respondenci wyrazili potrzebę wprowadzenia zmian na etykietach w przyszłości, a przede wszystkim podkreślili konieczność umieszczania w widocznym miejscu informacji o terminie przydatności do spożycia, jak również zróżnicowanie wielkości czcionki.

\section{Literatura}

BERNUÉS A., OLAIZOLA A., CORCORAN A. 2003: Labelling information demanded by European consumers and relationships with purchasing motives, quality and safety of meat. Meat Science 65 (3), 1095-1106.

BIESALSKI H., 2005: Meat as a component of a healthy diet - are there any risks or benefits if meat is avoided in the diet? Meat Science 3 (70), 509-524.

CEGIEŁKA A., 2010: Spożycie mięsa czerwonego - porównanie zagrożeń i korzyści. Gospodarka Mięsna 11, 18-19.

Consumer Attitudes to Food Standards. Wave 8. UK Report, Food Standard Agency 2007. http://www.food.gov. uk/multimedia/pdfs/cas2007ukreport.pdf, dostęp: 17.06.2014.

CROSS A.J., FERRUCCI L.M., RISCH A., GRAUBARD B.I., WARD M.H., PARK Y. et al., 2010: A large prospective study of meat consumption and colorectal cancer risk: an investigation of potential mechanisms underlying this association. Cancer Research, 70, 2406-2414.

GRUNERT K.G., WILLS J.M. 2007: A review of European research on consumer response to nutrition information on food labels. Journal of Public Health. 15, 385-399. 
GUTKOWSKA, K., SAJDAKOWSKA, M., ŻAKOWSKA-BIEMANS, S., KOSICKA-GĘBSKA, M., WIERZBICKI, J. 2013: Polish beef consumers: emerging or declining market? [in:] M. Klopčič, A. Kuipers, J.F. Hocquette: Consumer attitudes to food quality products : emphasis on Southern Europe, 275-285.

KONTOGIANNI M.D., PANAGIOTAKOS D.B., PITSAVOS C., CHRYSOHOOU C., STEFANADIS C., 2008: Relationship between meat intake and the development of acute coronary syndromes: The CARDIO2000 case - control study. European Journal of Clinical Nutrition 62, 171-177.

KOSICKA-GĘBSKA M., 2013: Zachowania polskich konsumentów na rynku wołowiny. Wydawnictwo SGGW, Warszawa.

KOSICKA-GĘBSKA M., 2012: Informacje umieszczane na opakowaniu paczkowanego mięsa drobiowego jako podstawa w budowaniu wiedzy konsumenta o produkcie. Handel Wewnętrzny, maj-czerwiec, 3, 241-250.

MCAFEE A.J., MCSORLEY E.M., CUSKELLY G.J., MOSS G.W., WALLACE J.M.W., BONHAM M.P., FEARON A.M. 2010: Red meat consumption: An overview of the risks and benefits. Meat Science 84, 1-13.

PIOTROWSKA A., ŚWIĄDER K., WASZKIEWICZ-ROBAK B., SWIDERSKI F. 2012: Możliwości uzyskania mięsa i przetworów z mięsa wieprzowego o podwyższonej zawartości wielonienasyconych kwasów tłuszczowych n-3. Żywność. Nauka. Technologia. Jakość 5 (84), 5-19.

POŁOM A., BARYŁKO-PIEKIELNA N., 2004: Analiza czynników decydujących o preferencjach polskich konsumentów mięsa wieprzowego. Żywność. Nauka. Technologia. Jakość 3 (40), 5-23.

Report on European Consumers' Percept of Foodstuff Labelling. Results of Consumer Research conducted on behalf of BEUC from February to April, 2005. http://www.beuc. org/BEUCNoFrame/ Docs/3/IFHIOGJCENFPHBEEJIKNOOIDPDB19 DBN7Y9DW3571KM/BEUC/docs/DLS/2005-00692-01-E.pdf, 2005, dostęp: 17.04.2014.

ROOSEN J., LUSK J.L., FOX J.A., 2001: Beef Labeling Strategies in France, Germany, and the UK, American Agricultural Economics, D 120, 1-24.

SADOWSKA A., ŚWIDERSKI F., 2010: Zwiazki bioaktywne w mięsie. Post. Techn. Przetw. Spoż., 1 (20/36), 70-74.

TOMASZEWSKA-PIELACHA M., OZIMEK I., 2011: Czytelność, zrozumiałość i kompletność informacji zamieszczanych na opakowaniach żywności w opinii konsumentów. Probl Higieny i Epidemiologii 92 (4), 820-823.

VALSTA L.M., TAPANAINEN H., MÄNNISTÖ S., 2005: Meat fats in nutrition. Meat Science 3 (70), 525-530.

VERBEKE W., PÉREZ-CUETO F.J.A., DE BARCELLOS M.D., KRYSTALLIS A., GRUNERT K.G. 2010: European citizen and consumer attitudes and preferences regarding beef and pork. Meat Science 84, 284-292.

VERBEKE W., VIAENE J., 2000: Ethical challenges for livstock production: Meetinh consumer concerns about meat safety and animal welfare. Journal of Agricultural and Environmntal Ethics 12, 141-151.

VERBEKE W., VIAENE J. 1999: Consumer attitude to beef quality labeling and associations with beef quality labels. Journal of International Food \& Agribusiness Marketing $10,45-65$. 


\section{4}

WALKOWIAK M., GUTKOWSKA K., JASIŃSKI C. 2012: Przyczyny spożywania mięsa $i$ wędlin przez polskich konsumentów. [w:] Gutkowska K. (red. nauk.): Możliwości rozwoju rynku wołowiny w Polsce w kontekście zachowań konsumentów wobec mięsa - odniesienia międzynarodowe. Wydawnictwo SGGW, Warszawa, 22-38.

WALKOWSKA S., REJMAN K., 2012: Wpływ dobrowolnych programów znakowania produktów spożywczych wartościq odżywczq na ksztattowanie prozdrowotnych zachowań na rynku żywności. Handel Wewnętrzny, t. III, 150-158.

WILLS J.M., SCHMIDT D.B., PILLO-BLOCKA F., CAIRNS G., 2009: Exploring global consumer attitudes toward nutrition information on food labels. Nutrition Reviews 67 (Suppl. 1), S102-S106.

YEN S.T., LIN B.H., DAVIS CH.G., 2008: Consumer knowledge and meat consumption at home and away from home. Food Policy 33, 631-639.

Zachowania i nawyki żywieniowe Polaków, 2010: Komunikat z badań CBOS, BS/150/2010, badanie „Aktualne problemy i wydarzenia” (245), 7-13.10, 2010, reprezentatywna próba losowa dorosłych mieszkańców Polski, $\mathrm{N}=1035$.

\section{Abstrakt}

Współczesny konsument, decydując się na zakup wieprzowiny, coraz częściej ze względu na własną wygodę oraz bezpieczeństwo, nabywa ją w formie pakowanej. Dokładnej wiedzy o produkcie dostarcza mu własna ocena sensoryczna mięsa związana przede wszystkim z oceną jego barwy oraz etykieta, na której producent zobowiązany jest do przekazania podstawowych, czytelnych i zrozumiałych informacji o produkcie. Jak dowodzą wyniki badania ilościowego przeprowadzonego w 2012 roku wśród 1325 konsumentów spożywających mięso wieprzowe, dla ponad $1 / 2$ ogółu populacji informacje zawarte na etykiecie pakowanego mięsa wieprzowego są mało widoczne (mało czytelne) i niezrozumiałe. Stąd też konsumenci oczekują w przyszłości konkretnych zmian, a przede wszystkim związanych z umieszczaniem w widocznym miejscu informacji o terminie przydatności wieprzowiny do spożycia $(29,1 \%)$, różnicowania wielkości czcionki $(26,8 \%)$ oraz informacji, że mięso jest wolne od jakichkolwiek składników pochodzących z substancji modyfikowanych genetycznie $(19,4 \%)$.

Słowa kluczowe: etykieta, informacja, wieprzowina, konsument 


\section{Assessment of information displayed on labels of packaged pork}

\section{Abstract}

Modern consumers are increasingly opting to buy pork in packaged form, for their own comfort and safety. Thorough knowledge of the product is derived from two sources. The first is the consumers' own sensory evaluation of meat, mainly based on its color. The second is the label, on which manufacturer is obliged to provide basic, clear and understandable information about the product, according to the guidelines of the European Parliament of the Regulation (EU) No 1169/2011 of the October 25, 2011, applied in Poland since 13 December 2014.

According to the results of quantitative survey conducted in 2012 on 1325 consumers of pork, for more than $1 / 2$ of the total population the information on the label of packaged pork are barely visible (barely legible) and incomprehensible. Hence, consumers expect in the future concrete changes. First of all, posting in a visible place the information concerning the pork shelf life (29.1\%), differentiating the font size (26.8\%), and the information that the meat is free of any genetically modified components (19.4\%).

Key words: label, information, pork, consumer 